vice-president of the International Association of Meteorology and Atmospheric Physics, and a member of the NATO Advisory Group on Meteorology. He has published numerous scientific articles, etc. His main research interests are in mathematical and dynamical meteorology, its application to weather forecasting, and the detailed investigation of the evolution and development of weather systems.

\section{Prof. W. V. Mayneord, F.R.S.}

Prof. W. V. Mayneord has been awarded the Gold Medal Pro Meritis Protectione Contra Radiationem of the Royal Swedish Academy of Seience. The Medal will be presented to Prof. Mayneord at the eleventh International Congress of Radiology, which will be held in Rome in September 1965. Until his retirement in September 1964, Prof. Mayneord was professor of physics as applied to medicine in the University of London, and director of the Department of Physics in the Institute of Cancer Research, Royal Cancer Hospital, London. He was a member of the International Commission on Radiological Protection during 1950-59; from 1950 until 1956 he was ehairman of the Commission's committee on protection against high-energy radiations (see Nature, 204, 22; 1964).

\section{Central Veterinary Laboratory, Weybridge :}

\section{Dr. A. B. Paterson}

Dr. A. B. Paterson has been promoted deputy director of the Central Veterinary Laboratory, Weybridge, following the death of Mr. J. L. McGirr. Dr. Patterson graduated from Glasgow Veterinary College in 1941. He joined the staff of the Biochemistry Department at the Central Veterinary Laboratory in 1944 efter undertaking postgraduate training in chemistry during the tenure of an Agricultural Research Council grant. A.fter work in the field of metabolic diseases of cattle, he took charge of tuberculin production and research, being promoted senior research officer, Grade 2, in 1950. Dr. Paterson was awarded a Ph.D. degree by the University of London in 1954, and became a Fellow of the Royal Institute of Chemistry in 1958. In 1959 he became senior research officer (Grade I) in charge of the Virology Department.

\section{Psychiatry in the University of Manchester:}

Prof. E. W. Anderson

Prof. E. W. Anderson, who has been professor of psychiatry in the University of Manchester since 1949, has been appointed a medical visitor in the office of the Lord Chancellor and will relinquish the chair of psychiatry on September 30 .

\section{Prof. W. I. N. Kessel}

DR. W. I. N. Kesser has been appointed to succeed Prof. Anderson, from a date to be arranged. Dr. Kessel is at present assistant director of the Medical Research Council Unit for Research on the Epidemiology of Psychiatric Illness and honorary senior lecturer in the Department of Psychological Medicine of the University of Edinburgh. Dr. Kessel was educated at Highgate School and Trinity College, Cambridge, where he was awarded a B.A. degree in 1945 and M.B., B.Chir. in 1949. In 1958 he obtained the diploma in psychological medicine of the University of London with distinction and was awarded an M.D.(Cambridge) in 1963. After qualification he was for one year a house surgeon in University College Hospital, London, and then held successively posts as house physician in the West Middlesex and St. Mary Abbotts Hospitals and medical registrar in St. Stephens Hospital, Chelsea. In 1953 he was appointed to the staff of the Maudsley Hospital where for the rext five years he held successively the posts of senior house officer, registrar and senior registrar, for the most part in the Professorial Unit. From 1960 he was for one year honorary senior registrar in the Psychiatric Department of University
College Hospital and since 1961 has held his present appointments in Edinburgh, where he has assumed responsibility for the psychiatric care of patients admitted to the emergency ward at the Royal Infirmary. Dr. Kessel's major research interests are in suicide and attempted suicide, the identification and estimation of psychiatric morbidity in general practice, and studies on the epidemiology of psychosomatic medicine. $\mathrm{H}_{\Theta}$ is the joint author of a book, Alcoholism, and in 1965 he delivered the Milroy Lectures to the Royal College of Physicians.

\section{Electrical and Control Engineering in Battersea College of Advanced Technology: $\quad$ Prof. D. R. Chick}

DR. D. R. CHIck has been appointed to a chair in, and tho headship of, the Department of Electrical and Control Engineering in Battersea College of Advanced Technology (University of Surrey at Guildford designate). Dr. Chick took his first degree in electrical engineering in 1937 and served in various posts dealing with military radio and radar to the end of the Second World War, in particular with the transmitters at Bawdsey and Christchurch, and earned a joint inventor's award for his work on searchlight radar control. He joined the new research laboratory of Associated Electrical Industries, Ltd., at Aldermaston, as a section leader responsible for developing the company's early interests in nuclear engineering, and later as a group leader he co-ordinated the thermonuclear and research reactor engineering. With the late Dr. Petrie he developed a successful radio-frequency travelling-wave accelerator for protons to boost the energy of particles leaving the high-voltage electrostatic generator which his Section had built, and he was awarded an M.Eng. by the University of London for this contribution, also an M.Sc. in physics by the University of Reading for his work on static machines. His engineering contributions to the thermonuclear work culminated in the successful operation of the Sceptre series of toroidal accelerators, and he gave overall guidance to the design, construction and operation of the first British research reactor, the 5-MW Merlin at Aldermaston. For his many original engineering papers he was awarded a. D. Eng. degree by the University of London. His work has kept him in close touch with research in many universities in the United Kingdom and overseas. He has spent the past two years with the Vickers research organization.

\section{Geography in the University of Edinburgh :}

Prof. J. T. Coppock

Dr. J. T. Coppock, reader in geography in University College, London, has been appointed to the newly instituted Ogilvie chair of geography. This chair is additional to the chair at present held by Prof. J. Wreford Watson. Dr. Coppock was born and went to school in Wales. After service during the Second World War, mainly in the Middle East, he went up to Queen's College, Cambridge, where he was a Foundation Scholar and obtained first-class honours in both Parts of the Geographical Tripos. After a further year at Cambridge as departmental demonstrator in geography, he was appointed in 1950 assistant lecturer in the Department of Geography in University College, London. Promoted to lecturer in 1952, he was accorded his present status of reader in 1964. During the academic session 1963-64 he was visiting senior lecturer in the Department of Geography at the University of Ibadan, Nigeria. He was awarded the degree of M.A. by the University of Cambridge in 1953 and the degree of Ph.D. by the University of London in 1960. Dr. Coppock's principal research interests have lain in the fields of economic and historical geography with particular reference to the geography of agriculture and the problems of rural land-use and land-use competition. In collaboration with $R$. H. Best he has published a study of land-use changes in Great Britain, and he has recently been appointed a member of the England Committee of 